\title{
Effect of Peptide Chain Length on Absorption and Intact Transport of Hydrolyzed Soybean Peptide in Rat Intestinal Everted Sac
}

\author{
Hwal Chun, ${ }^{*}$ Masaya SASAKI, Yoshihide FuJIYAma, \\ and Tadao BAMBA \\ Second Department of Internal Medicine, Shiga University of \\ Medical Science, Otsu 520-21, Japan
}

(Received May 14, 1996)

\begin{abstract}
Summary In this study using everted sacs of rat jejunum, we investigated the difference in absorption of two types of soybean peptides (small peptide: SP, and large peptide: LP). We investigated the influence of peptide length on absorption and intact transport of hydrolyzed soybean peptides. The everted sacs were incubated for 5 or $10 \mathrm{~min}$ in bicarbonate-saline buffer containing a $1 \%(\mathrm{w} / \mathrm{v})$ concentration of each soybean peptide. After the incubation, the amounts of free amino acids and peptides that were transported to the serosal fluids and the mucosa were measured with an automatic amino acid analyzer both before and after the hydrolysis of the serosal fluids and mucosa. The results indicated that SP was absorbed more rapidly than LP and that the more rapid absorption of SP was due to the greater intact transport of SP. When the everted sacs were made from jejunum that had been injured by intraperitoneal injection of cyclophosphamide $(300 \mathrm{mg} / \mathrm{kg}$ ), no significant differences were noted between the absorption of SP and that of LP. We also ascertained that an aminopeptidase inhibitor (bestatin) decreased the aminopeptidase activities of the rat jejunum. In the presence of $1 \times 10^{-4}$ $M$ bestatin in the incubation buffer, no significant differences were noted between the absorption of SP and that of LP. We conclude that SP is absorbed more rapidly than LP in normal rat jejunum due to greater intact transport.
\end{abstract}

Key Words: small peptide, everted sac intestine, intact transport, soybean hydrolysate, aminopeptidase inhibitor

${ }^{*}$ To whom correspondence should be addressed. 
Dietary protein is known to be converted to oligopeptides and amino acids in the intestine after digestion in the stomach and duodenum. Oligopeptides become dipeptides and tripeptides after hydrolysis by aminopeptidase in the brush border membrane in the intestine. It has also been recognized that not only amino acids, but also intact dipeptides and tripeptides are transported through the mucosal membrane $[1,2]$. Moreover, dipeptides and tripeptides are absorbed more rapidly and reach a higher concentration compared to amino acids [3]. We previously found, using intestinal everted sacs of rats fed a diet containing small peptides as the nitrogen source, that the absorption of glycyl-L-leucine was significantly increased as well as that of glycine and L-leucine [4]. We have also demonstrated the advantage of using oligopeptide rather than amino acids as the nitrogen source from the viewpoint of peptidase activities as well as absorption of amino acids [5].

In the present study using everted sacs of rat intestine, we evaluated the effect of the peptide length of soybean hydrolysate on absorption of amino acids and peptides. We also evaluated the absorption of peptides in everted rat intestine after injury with cyclophosphamide (CPM). Moreover, we investigated the effect of aminopeptidase inhibitor on the absorption of two types of peptides.

\section{MATERIALS AND METHODS}

Animals and food. Male Wistar rats (250-300 g, Clea, Osaka) were kept at room temperature of $25 \pm 2^{\circ} \mathrm{C}, 55 \pm 5 \%$ humidity under 12 -h light/12-h dark cycle (light: $8.00-20.00 \mathrm{~h}$ ) and allowed free access to normal pellet diet (CE-2, Clea) and water.

Two types of soybean peptides. Table 1 shows the composition of two types of soybean hydrolysate (Fuji Seiyu, Osaka). Two types of soybean hydrolysate were prepared from a single protein source. The amino acid compositions of each hydrolysate were almost identical. The average peptide chain length of the small peptide (SP) was 3.2; and that of the large peptide (LP), 5.2.

Preparation of everted intestine sacs and absorption test of peptides. We performed in vitro absorption tests using everted sacs of the rat jejunum by the method of Wilson and Wiseman [6]. SP or LP was dissolved at $1 \%(\mathrm{w} / \mathrm{v})$ concentration in a buffer solution containing $133 \mathrm{mM} \mathrm{NaCl}, 4.7 \mathrm{mM} \mathrm{KCl}, 3.2 \mathrm{mM}$ $\mathrm{CaCl}_{2}, 16.3 \mathrm{mM} \mathrm{NaHCO}, 1.8 \mathrm{mM} \mathrm{NaH}_{2} \mathrm{PO}_{4}, 0.21 \mathrm{mM} \mathrm{MgCl}_{2}$, and $7.7 \mathrm{~mm}$ glucose. The everted intestinal sacs were incubated in either solution under $95 \% \mathrm{O}_{2}$ and $5 \%$ $\mathrm{CO}_{2}$ at $37^{\circ} \mathrm{C}$ for 5 or $10 \mathrm{~min}$, and washed immediately with ice-cold isotonic mannitol solution. Both serosal fluids and intestinal mucosa were obtained from each of the everted sacs. The mucosal samples were scraped and homogenized after addition of the buffer solution. The content of protein in the intestinal mucosa of each everted sac was determined by the method of Lowry [7]. After treatment with trichloroacetic acid, $0.6 \mathrm{ml}$ of $10 \mathrm{~N} \mathrm{HCl}$ was added to each $0.4-\mathrm{ml}$ samples, and the samples were hydrolyzed at $110^{\circ} \mathrm{C}$ for $24 \mathrm{~h}$ for amino acid analysis.

Amino acid and peptide analysis. The amino acid compositions of the 
Table 1. Composition of the two types of soybean protein.

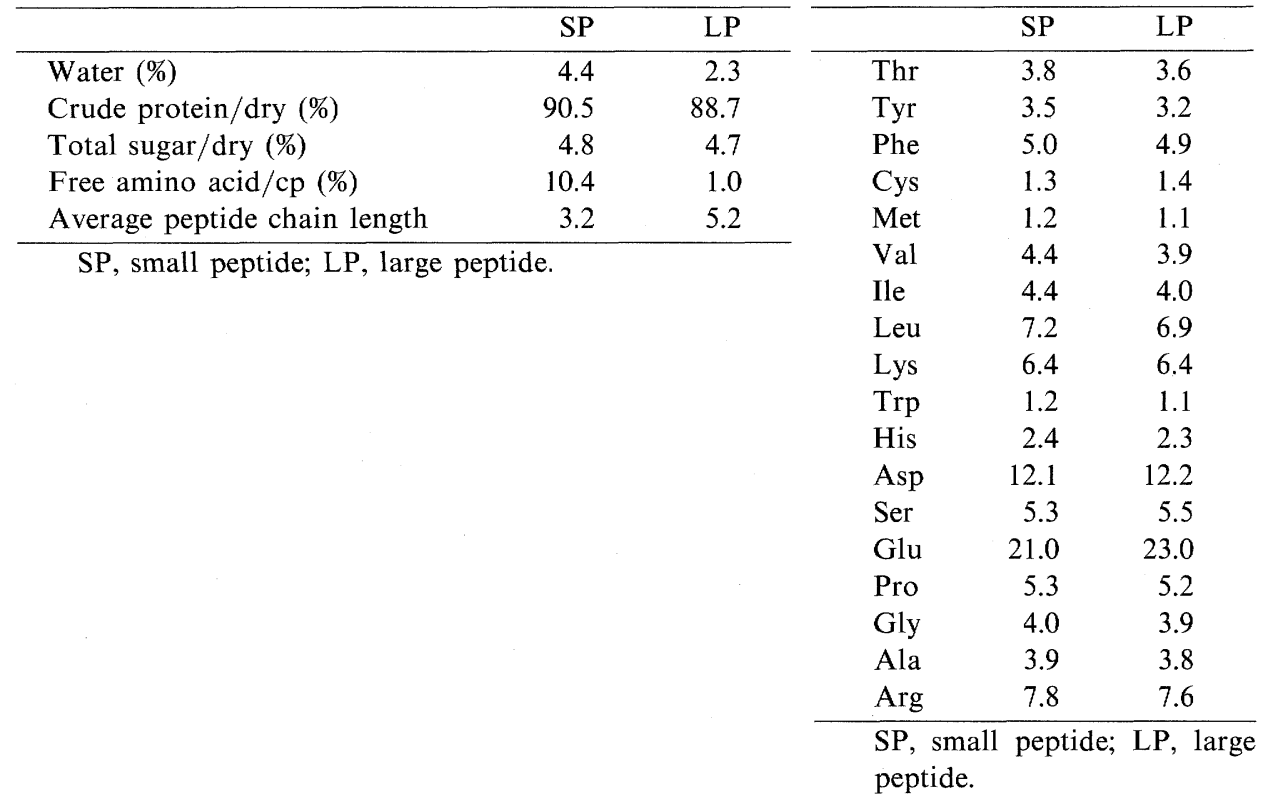

serosal fluid and the intestinal mucosa were analyzed with an automatic amino acid analyzer (Hitachi L-8500, Hitachi, Tokyo) both before and after the hydrolysis of the serosal fluids and mucosa. Tryptophan was excluded from consideration because of its massive destruction on acid hydrolysis [8]. Serine and threonine were also excluded from consideration because of their destruction on acid hydrolysis.

The total amount of peptide or amino acids incorporated by the mucosa and serosal fluids was calculated as follows:

$$
\text { Mucosal uptake }=\frac{\text { AA (after incubation) }- \text { AA (before incubation) }}{\mathrm{mg} \text { protein }} \text {, }
$$

$$
\text { Total uptake }=\frac{\text { AA of serosal fluid }}{\mathrm{mg} \text { protein }}+\text { mucosal uptake, }
$$

where AA is the amino acid content.

The methods for investigation of peptide absorption were essentially those previously used by Gardner [9-11]. The amino acid compositions of the serosal fluid and the intestinal mucosa analyzed before the hydrolysis indicated the uptake of peptides as free amino acids. Peptide- $\mathrm{N}$ was estimated as bound-N by the difference method, i.e., from the the increase in free amino acid on acid hydrolysis [10-12]. Intact transport was calculated as follows:

Intact transport $=$ total uptake - uptake as free amino acids.

Method of administration of cyclophosphamide (CPM). CPM (Shionogi, Osaka) dissolved in distilled water $(40 \mathrm{mg} / \mathrm{ml})$ was administered intraperitoneally Vol. 21, No. 2, 1996 
at a dose of $300 \mathrm{mg} / \mathrm{kg}$ body weight. Three days after administration of CPM, the absorption test for the peptides was performed as described above.

Assay of brush border membrane enzyme activities. The aminopeptidase activities of the mucosa were measured by the amino salicylic acid method with L-leucyl-3-carboxy-4-hydroxyanilide as the substrate [13]. Alkaline phosphatase activity was assayed by the method of King [14].

Assay of aminopeptidase activities in the presence of aminopeptidase inhibitor and absorption test for peptides in the presence of aminopeptidase inhibitor. The influence of an aminopeptidase inhibitor (bestatin, [(2S,3R)-3-amino-2-hydroxy-4-phenylbutanoyl]-L-leucine, Nihon Kayaku, Tokyo) was evaluated by measuring the aminopeptidase activities of the mucosa as described above in the presence of $10^{-3}-10^{-8} \mathrm{M}$ aminopeptidase inhibitor in the homogenate of the jejunal mucosa. The absorption test for peptides was performed as described above in the presence of $1 \times 10^{-4} \mathrm{M}$ aminopeptidase inhibitor in the incubating buffer.

Calculations and statistical analysis. Results were expressed as the mean and standard error of the mean. Statistical comparisons were conducted with Student's $t$-test. A $p$ value of less than 0.05 was considered significant.
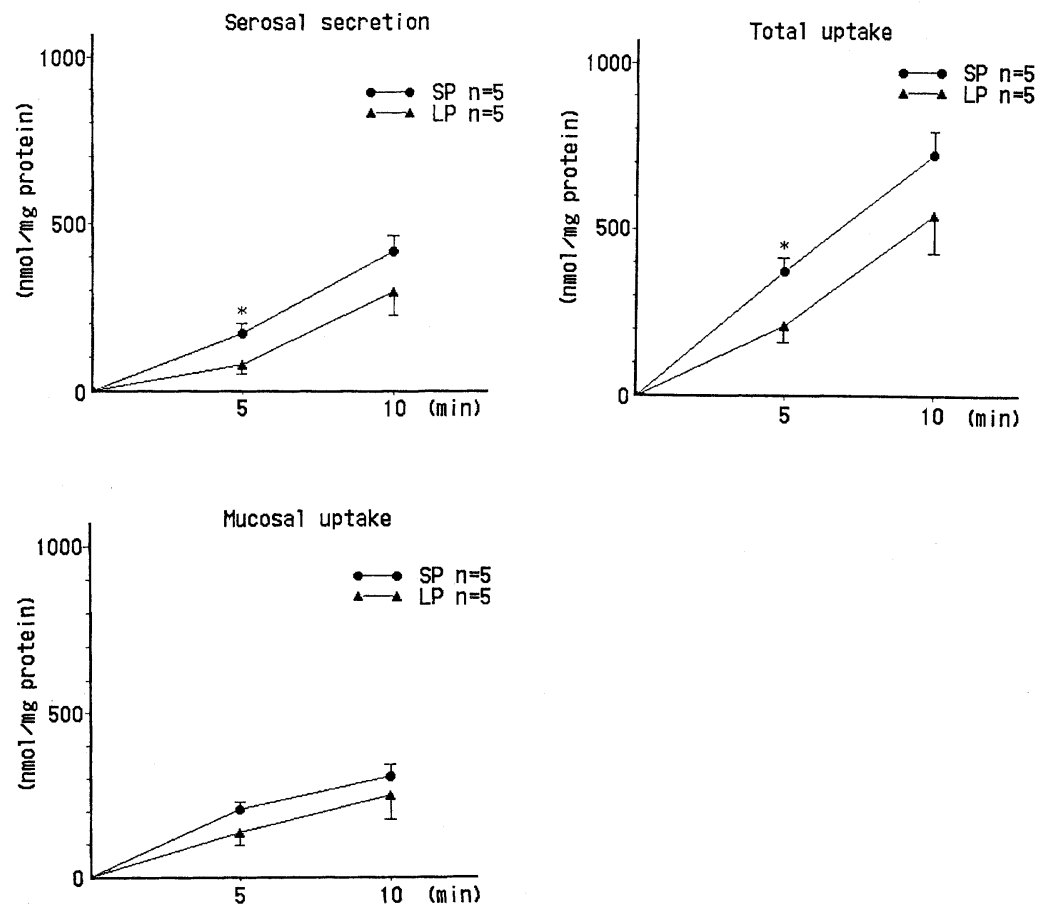

Fig. 1. Time course of absorption of two types of soybean peptides by everted sacs of rat jejunum. SP, small peptide; LP, large peptide. Each point represents the mean \pm SEM. ${ }^{*} p<0.05$ : significant difference between amounts of absorption of SP and LP. 


\section{RESULTS}

\section{Peptide and amino acid absorption in the normal mucosa}

The amounts of amino acids and peptides that were absorbed into the serosal fluids and mucosa of the everted sacs are shown in Fig. 1. The total uptake of SP was significantly greater than that of LP at $5 \mathrm{~min}$, but there was no difference between total uptakes of SP and LP at $10 \mathrm{~min}$. The absorption of SP into serosal fluids was significantly greater than that of LP at $5 \mathrm{~min}$.
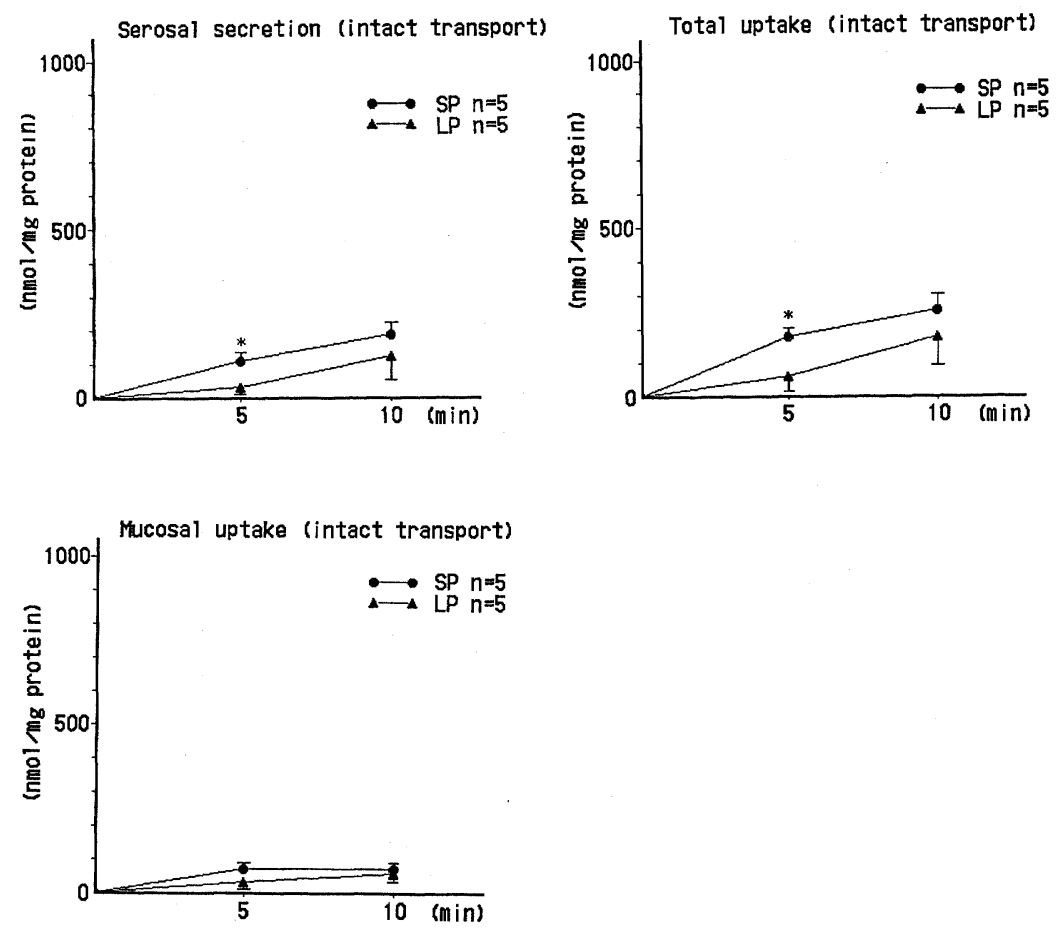

Fig. 2. Intact transport of two types of soybean peptide from everted sacs of rat jejunum. SP, small peptide; LP, large peptide. Each point represents the mean \pm SEM. ${ }^{*} p<0.05$ : significant difference between amounts of absorption of SP and LP.

Table 2. Effect of CPM on body weight and mucosal parameters.

\begin{tabular}{lcccc}
\hline Group & $\begin{array}{c}\text { Body weight } \\
\text { change } \\
(\mathrm{g} / 3 \text { days })\end{array}$ & $\begin{array}{c}\text { Mucosal } \\
\text { protein } \\
(\mathrm{mg} / \mathrm{cm})\end{array}$ & $\begin{array}{c}\text { Alkaline } \\
\text { phosphatase } \\
(\mathrm{IU} / \mathrm{g} \text { protein })\end{array}$ & $\begin{array}{c}\text { Leucine } \\
\text { aminopeptidase } \\
(\mathrm{IU} / \mathrm{g} \text { protein })\end{array}$ \\
\hline Control $(n=5)$ & $7.8 \pm 1.8$ & $2.62 \pm 0.52$ & $1,129 \pm 177$ & $86.2 \pm 4.0$ \\
CPM $(n=5)$ & $-35.5 \pm 2.6^{* *}$ & $2.25 \pm 0.19$ & $826 \pm 111$ & $57.8 \pm 9.3^{*}$ \\
\hline
\end{tabular}

CPM, cyclophosphamide. The values are expressed as means \pm SEM. Significant difference between control and CPM group. ${ }^{*} p<0.05,{ }^{* *} p<0.01$.

Vol. 21, No. 2, 1996 
Peptide absorption via intact transport

The amount of the intact transport of SP was greater than that of LP at $5 \mathrm{~min}$, but there was no difference between the intact transports of SP and LP at $10 \mathrm{~min}$ (Fig. 2).

\section{Effects of CPM on mucosal parameters}

The aminopeptidase activities in the mucosa of rats obtained 3 days after administration of CPM were significantly lower than those of the control mucosa (Table 2). The mucosal protein and alkaline phosphatase activities of rats 3 days after administration of CPM were also lower than those of the control.

\section{Peptide and amino acid absorption in the mucosa injured by CPM}

There was no significant difference between SP and LP for total uptake of peptide and amino acid at 5 or $10 \mathrm{~min}$ in the everted sac of jejunum injured by CPM administration (Fig. 3). There was also no significant difference between SP and LP for intact transport at 5 or $10 \mathrm{~min}$.
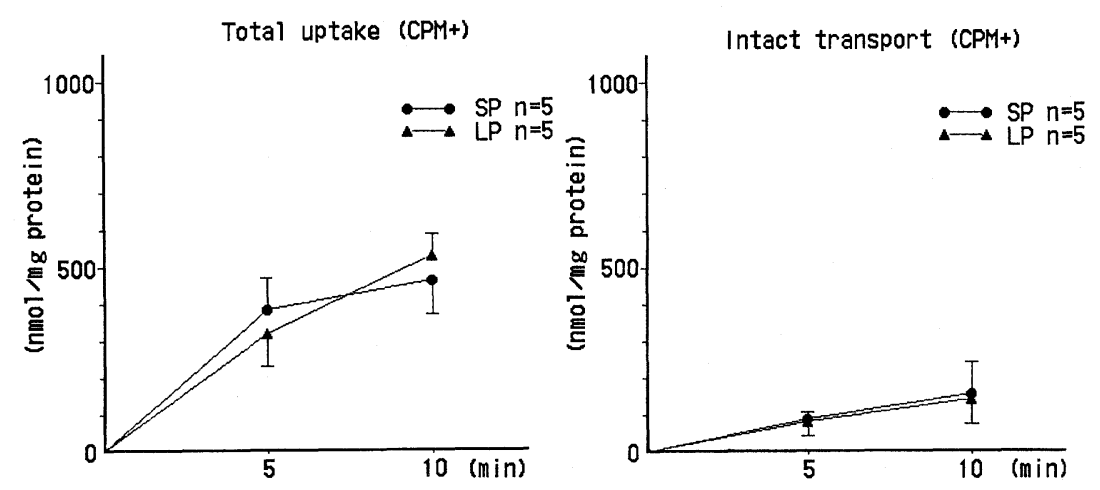

Fig. 3. Time course of absorption of each of the two types of soybean peptides by everted sacs of jejunum obtained from rats 3 days after intraperitoneal injection of CPM. SP, small peptide; LP, large peptide. Each point represents the mean \pm SEM. ${ }^{*} p<0.05$ : significant difference between amounts of absorption of SP and LP.

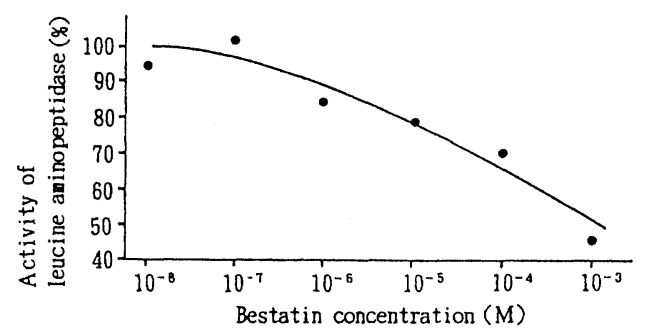

Fig. 4. Effect of bestatin on leucine aminopeptidase activity of rat jejunum.

J. Clin. Biochem. Nutr. 
Total uptake (bestatin+)

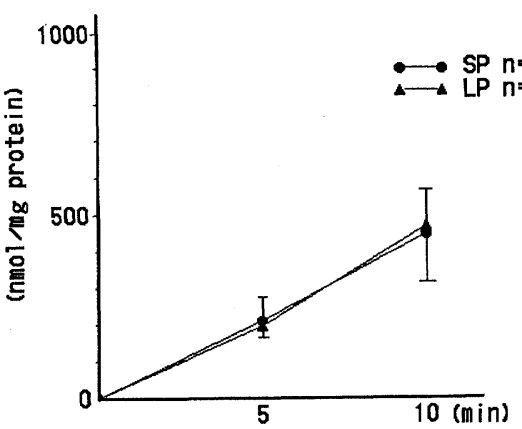

Intact transport ( bestatin+)

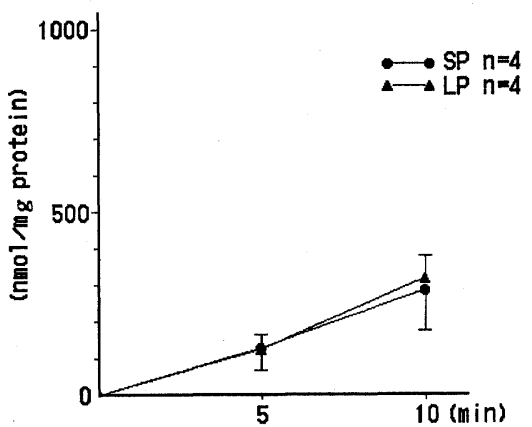

Fig. 5. Time course of absorption of each of the two types of soybean peptides by everted sacs of rat jejunum in the presence of bestatin $\left(1 \times 10^{-4} \mathrm{M}\right)$ in the buffer. SP, small peptide; LP, large peptide. Each point represents the mean \pm SEM. ${ }^{*} p<0.05$ : significant difference between amounts of absorption of SP and LP.

Peptide and amino acid absorption in the presence of aminopeptidase inhibitor

There was a dose-dependent decrease in the aminopeptidase activities of the intestinal mucosa with an increase in the concentration of aminopeptidase inhibitor (Fig. 4).

In the presence of $1 \times 10^{-4} \mathrm{M}$ aminopeptidase inhibitor, there was no significant difference between SP and LP for total uptake of peptide and amino acid at 5 or $10 \mathrm{~min}$. There was also no significant difference in intact transport at 5 or 10 $\min$ (Fig. 5).

\section{DISCUSSION}

It is reported that the chain length of the constituent peptides has an important influence on the absorptive properties of partial enzymic hydrolysates [15], but the effect of peptide chain length on intact transport has not been reported. In this study, SP was absorbed significantly more rapidly than LP in the everted rat jejunum. We consider that the more rapid absorption of SP is due to the greater intact transport of these peptides. It is recognized that the absorption of peptides is more rapid than that of amino acids [3]. It is also reported that intestinal mucosal permeation of large peptides like pentapeptide is poor $[16,17]$ and that the membrane permeation of the large peptide is affected by an aminopeptidase inhibitor and a permeability enhancer [17]. In this study, rapid absorption of peptides, which mainly consisted of di- and tripeptides, was observed in the absorption test using soybean peptides; the average soybean peptide chain length of the SP was 3.2, and that of the LP was 5.2. These data suggest that absorption of di- and tripeptides would be more rapid than that of large peptides consisting of penta- or hexapeptides, and that intact transport of peptides would be greater 
for transport of di- and tripeptides. When absorption of casein and casein hydrolysate was studied, the differences between the effects of casein and casein hydrolysate were considered to depend on the rate of protease digestion, since casein should be hydrolyzed by pancreatic enzymes [18].

Intestinal amino acid transport is regulated in a complex way by hydrolyzed levels of protein, protein hydrolysates, or amino acids [19, 20], and intestinal amino acid transporters are regulated semi-independently of each other [21]. It was reported that Gly-Leu is absorbed by two distinct pathways: $\mathrm{Na}^{+}$-dependent absorption involving hydrolysis by brush border membrane aminopeptidases and $\mathrm{H}^{+}$-dependent absorption of intact peptides [22]. In this study, transport of intact peptides was evident in the absorption of both types of soybean hydrolysate, SP and LP.

Severe impairment of intestinal absorption after administration of 5-fluorouracil has already been shown in the rat; and alteration of intestinal enzyme activities has also been shown $[23,24]$. We reported earlier that glycine transport carrier is more sensitive to CPM injury than is the peptide transport carrier for glycine-containing dipeptides in the rat [25]. In this study, in the mucosa injured by CPM, there was no difference in absorption between SP and LP. The decreased aminopeptidase activities and injury of transporters of amino acids could cause decreased absorption of both SP and LP, and the decreased absorption of these two types of peptides could result in the absence of a difference in absorption between SP and LP.

Aminopeptidase inhibitor is recognized to competitively inhibit hydrolysis of dipeptides and noncompetitively inhibit absorption of dipeptides [26]. Bestatin is one of exopeptidase inhibitors and a low molecular weight inhibitor of hydrolytic enzymes on the surfaces of cells [27]. It is reported that bestatin inhibited half the dipeptide absorption at $10^{-4} \mathrm{M}$, but only minimally inhibited the absorption of constituent amino acids [26]. In this study, in the presence of aminopeptidase inhibitor, the aminopeptidase activity showed a dose-dependent inverse relationship with the concentration of aminopeptidase inhibitor. In the presence of aminopeptidase inhibitor, the absorption of both SP and LP was decreased compared with the absorption obtained without aminopeptidase inhibitor, and there was no difference in absorption between SP and LP.

Peptides are currently used as a nitrogen source in chemically defined diet because peptides are more effectively absorbed than free amino acids [28, 29]. It is also suggested that enzymatically hydrolyzed proteins are utilized more efficiently than mixtures of amino acids in the absence of exocrine pancreatic function [30]. Based on our data, SP is absorbed more rapidly than is LP by the jejunum of the normal rat intestine, and the peptides of a soybean hydrolysate are absorbed effectively as a source of nitrogen in the rat small intestine.

We thank Noboru Urushiyama for assistance with the amino acid analysis. This work was partially supported by Fuji Seiyu Company. 


\section{REFERENCES}

1. Matthews, D.M. (1975): Intestinal absorption of peptides. Physiol. Rev., 55, 537-608.

2. Webb, K.E., Dirienzo, D.B., and Matthews, J.C. (1992): Recent developments in gastrointestinal absorption and tissue utilization of peptides. J. Dairy Sci., 76, 351-361.

3. Claft, I.L., Deddes, D., and Matthews, D.M. (1968): Absorption and malabsorption of glycine and glycine peptides in man. Gut, 9, 425-437.

4. Sasaki, M., Bamba, T., and Hosoda, S. (1989): Intestinal brush border membrane enzyme activities of rats fed chemically defined diets containing oligopeptides or amino acids as the nitrogen source. J. Clin. Biochem. Nutr., 7, 231-241.

5. Bamba, T., Fuse, K., Obata, H., Sasaki, M., and Hosoda, S. (1993): Effects of small peptides as intraluminal substrates on transport carriers for amino acids and peptides. J. Clin. Biochem. Nutr., 15, 33-42.

6. Wilson, T.H., and Wiseman, G. (1954): The use of sacs of everted small intestine for the study of the transference of substances from the mucosal to the serosal surface. J. Physiol., 123, $116-125$.

7. Lowry, O.H., Rosegrough, N.J., Farr, A.L., and Randall, R.J. (1951): Protein measurement with the Folin phenol reagent. J. Biol. Chem., 193, 265-275.

8. Gardner, M.L.G., Lindblad, B., Burston, D., and Matthews, D.M. (1983): Transmucosal passage of intact peptides in the guinea-pig small intestine in vivo: A reappraisal. Clin. Sci., 64, 433-439.

9. Gardner, M.L.G. (1975): Absorption of amino acids and peptides from a complex mixture in the isolated small intestine of rat. J. Physiol., 253, 233-256.

10. Gardner, M.L.G. (1978): Amino acid and peptide absorption from partial digests of proteins in isolated rat small intestine. J. Physiol., 284, 83-104.

11. Gardner, M.L.G. (1982): Absorption of intact peptides: Studies on transport of protein digests and dipeptides across rat small intestine in vitro. Q. J. Exp. Physiol., 67, 629-637.

12. Stein, M.H., and Moore, S. (1954): The free amino acids of human blood plasma. J. Biol. Chem., 211, 915-926.

13. Shimamoto, M., Takewaki, S., Sakuraoka, S., Nagasawa, T., Kuroiwa, K., Kodama, O., and Akatsuka, T. (1985): Use of L-leucyl-3-carboxy-4-hydroxyanilide as substrate for determining the activity of microsomal aminopeptidase in serum. Clin. Chem., 31, 1636-1639.

14. Kind, P.R.N., and King, E.J. (1954): Estimation of plasma phosphatase by hydrolysed phenol with amino-antipyrine. J. Clin. Pathol., 7, 322-326.

15. Grimble, G.K., Keohane, P.P., Higgins, B.E., Kaminski, M.V., and Silk, D.B.A. (1986): Effect of peptide chain length on amino acid and nitrogen absorption from two lactalbumin hydrolysates in the normal human jejunum. Clin. Sci., 71, 65-69.

16. Amidon, G.L., and Lee, H.J. (1994): Absorption of peptide and peptidomimetic drugs. Annu. Rev. Pharmacol. Toxicol., 34, 321-341.

17. Aungst, B.J., Blake, J.A., and Hussain, M.A. (1991): An in vitro evaluation of metabolism and poor membrane permeation impending intestinal absorption of leucine enkephalin and methods to increase absorption. J. Pharmacol. Exp. Ther., 259, 139-145.

18. Gardner, M.L.G. (1980): Absorption of intact peptides: Studies on transport of protein digests and dipeptides across rat small intestine in vitro. J. Exp. Physiol., 67, 629-637.

19. Karasov, W.H., Solberg, D.H., Chan, S.D., Hughes, M., Stein, E.D., and Dimond, J.M. (1985): Is intestinal transport of sugars and amino acids subject to critical-period programming? Am. J. Physiol., 249, G770-G785.

20. Karasov, W.H., Solberg, D.H., and Dimond, J.M. (1987): Dependence of intestinal amino acid uptake on dietary protein or amino acid levels. Am. J. Physiol., 252, G614-G625.

21. Stein, E.D., Chan, S.D., and Dimond, J.M. (1987): Comparison of different dietary amino acids as inducers of intestinal amino acid transporters. Am. J. Physiol., 252, G626-G635.

22. Himukai, M., and Hoshi, T. (1980): Mechanisms of glycyl-L-leucine uptake by guinea-pig

Vol. 21, No. 2, 1996 
small intestine: Relative importance of intact peptide transport. J. Physiol., 302, 155-169.

23. Gardner, M.L.G., Samson, R.R., and Heading, R.C. (1978): Changes in absorptive and peptide hydrolase activities in rat small intestine after administration of 5-fluorouracil. Clin. Sci. Mol. Med., 54, 411-418.

24. Gardner, M.L.G., and Heading, R.C. (1979): Effects of 'elemental' diets on absorptive and enzymic activities and on 5 -fluorouracil toxicity in rat small intestine. Clin. Sci., 56, 243249.

25. Hosoda, T., Bamba, T., and Hosoda, S. (1991): Ideal absorption of various amino acids and dipeptides in rats administered cyclophosphamide-Using the short-circuit current method. Nihon Shoukakibyou Gakkai Zasshi, 88, 2837-2846 (in Japanese with English abstract).

26. Yasumoto, K., and Sugiyama, K. (1980): Perturbation by bestatin of glycyl-L-leucine absorption in isolated epithelial cells from rat intestine. Agric. Biol. Chem., 44, 1339-1344.

27. Wikes, S.H., and Prescott, J.M. (1985): The slow, tight binding of bestatin and amastatin to aminopeptidases. J. Biol. Chem., 260, 13154-13162.

28. Silk, D.B.A., Fairclough, P.D., Clark, M.L., Hegarty, J.E., Marrs, T.C., Addison, L.M., Burston, D., Clegg, K.M., and Matthews, D.M. (1980): Use of a peptide rather than a free amino acid nitrogen source in chemically defined "elemental" diets. J. Parent. Ent. Nutr., 4, 548-553.

29. Hara, H., Funabiki, R., Iwata, M., and Yamazaki, K. (1984): Portal absorption of small peptides in rats under unrestrained conditions. J. Nutr., 114, 1122-1129.

30. Imondi, A.R., and Stradley, R.P. (1974): Utilization of enzymatically hydrolyzed soybean protein and crystalline amino acid diets by rats with exocrine pancreatic insufficiency. $J$. Nutr., 104, 793-801. 